\title{
University General Education and Music Appreciation
}

\author{
Yi-Jing XU ${ }^{1, a}$, Zhe ZHANG $^{2, b}$, Jian-Hua ZHANG ${ }^{3, c}$ \\ ${ }^{1}$ General Education Center, Beijing Normal University Zhuhai Campus, China \\ ${ }^{2}$ Shenyang Wen Ze Cultural Information Ltd., Shenyang, Xinghuanan Street, No.5, China \\ ${ }^{3}$ General Education Center, Beijing Normal University Zhuhai Campus, China \\ a845443202@qq.com, bengel2002@msn.com, czhuhaijianhua@aliyun.com
}

Keywords: Teaching reform, General education, Music appreciation, Piano culture.

\begin{abstract}
This paper first talked about the importance of music education in china. However, in recent years, because of various objective factors, which affected the musical education in primary school and secondary school. Early to enter university learning, the students lacked of different levels of the base knowledge, such as, the social science, natural science, artistic accomplishment and practice skills. How to give them make up the lesson, through the education of higher learning, train them to become excellent in character and learning a new generation youth, is each of our higher education educator's responsibility. This paper introduced the experience to carry out General Education teaching work in university, focus on how to set and operate the module curriculum in Art Literacy Curriculum, and with talked of music education in detail, the development of General Education curriculum, as well as the relationship between music education and General Education in University. This paper has unique insights, which can be a reference for the educational workers and reference.
\end{abstract}

\section{Significance of Music Education}

After the establishment of the new China, in primary and secondary schools, along with the popularization of the compulsory education, music education has been one of the important courses in primary and middle schools. It is one of important teching means inorder to set up the patriotism, revolutionary tradition education, to establish a correct outlook on life and world outlook. So far, music educational function has become more perfect, can be summed up as follows.

\section{Edify Sentiment}

Music, for the cultivation of noble emotion and aesthetic taste of people, it has other art plays an irreplaceable role. Music education has vivid, emotional, happy three basic characteristics, to enable students to fully enjoy all the beautiful music, music of these healthy can touch the heart of the students, cultivate sentiments of students, to make students quality become better.

\section{Education and Learning in Atmosphere of Joy}

Any ideological and moral education, if no emotional foundation, can only be empty talk, music as the realization of the role of ideological education tool, and not by the mandatory approach, which relies on music distinctive rhythm, melody, rich harmonies, the beauty of the sound to express themselves, which can directly touch the emotional center of students, shocked the students heart, is great for students emotional world, morality, moral infiltration and influence. Therefore, the school music education is very important.

\section{Music Is Wisdom of Enlightenment "key"}

The music education right on the development of children's intelligence is indeed has a positive role in promoting, can help students to understand the objective world, the expansion of knowledge. Music education right can promote the intellectual development of students, can improve the students' comprehensive quality. 


\section{Music Is Auxiliary Tools to Keep Fit}

The beautiful music can promote people's physical and mental health development, dance can develop the students ability to understand, the abstract music expressed through the body's sport, make students keep their flexible, body coordination and so on.In a word, the school music education should operated the development and virtue, wisdom, body train, beauty, laber, promote each other.

\section{Education Defect Under The Present Condition}

The uneven economic development in various regions, imbalance in educational development, and restricted the full implementation of music education.

Under the drawbacks of the current college entrance examination system, China's elementary education in the school, teaching pay attention to "college entrance examination subjects", and despise contempt even give up "non college entrance examination subjects", this is an abnormal teaching phenomenon. it influence and hinder the students comprehensive development.

In secondary schools in China, prematurely distinguish "liberal arts" and "science" course, is done separately teaching, inorder to improve the university enrollment rate, that is instant success teaching mode. This extremely harmful practices, so that after our students to enter colleges, both liberal arts, science and arts students, there are "be congenitally deficient" of knowledge imperfection, influence or even delayed the implementation of student's the final goal of education in higher education.

\section{University General Education}

Because of the existence of objective reality, China's colleges and universities, although have in the university curriculum and learning time is very tight, we have to add students' knowledge, these learning content should be in the primary or secondary education stage to study and complete. As the higher education workers, this is to fulfill their social responsibility. At present, our country university general education, not just a simple "in basic education and professional education teaching time allocation and the reform of teaching content" the surface of things, but more important is how to cultivate students to become "ideals, morality, all-round development new era of youth".

\section{Implementation of General Education in Colleges and Universities}

General education reform in Colleges and universities, the purpose must be to the education, to improve the quality of teaching as the core, with the characteristics of, teaching emphasis on strengthening the moral personality education of students, to cultivate the noble personality, extensive knowledge, have both ability and political integrity, all-round development of talents.

General Education teaching reform in the Humanities, prominent China traditional culture education of educational function, highlight the Chinese Ancient Chinese Literature Search function of moral education, while increasing the western culture education, training students' pioneering ability.

General Education teaching reform in social science, in the economics, management, law, education and teaching, it should be stressed in the frontier and cross knowledge, innovation emphasizes curriculum content and integration with the international frontier science and culture.

General Education teaching reform in natural science literacy, is inorder to increase scientific and technological courses, to strengthen science and technology content and the research method innovation. Advocate science and technology to the coordinated development of education and the humanities education, training students with the rigorous scientific attitude and scientific spirit of innovation.

General education teaching reform in the artistic accomplishment, aesthetic education is as the goal, focus on helping college students physical and mental health development is focus, create beautiful soul, culture perception, imagination, aesthetic ability, to cultivate students' good unified 
personality, aesthetic thought to guide students with harmony, symmetry, distinct constructs self, as a whole harmony and unity of appearance and spirit are very beautiful.

\section{How to Carry Out Teaching Music in General Education}

As mentioned before, music which relies on music distinctive rhythm, melody, rich harmonies, the beauty of the sound to express themselves, which can directly touch the emotional center of students, shocked the students heart, is great for students emotional world, morality, moral infiltration and influence.

According to the age of the students, and the cultural foundation and the social experience are the characteristics are different between the secondary school and in the university, General education setting music education curriculum categories can be as rich as possible, but curriculum time arrangement should not be too much, in this way, students can according to their own interests and hobbies, have more choices to study different courses.

Here particularly pointed out: to set up the "Piano culture" course, is to play an important role in improving the students' artistic accomplishment.

The piano is in China, can be said to be the product of East West Economic and cultural exchanges. In early twentieth Century, piano culture began to spread in China, and in the process of development, gradually merging with the China traditional music culture, the formation of with China characteristics piano culture.Now, which is of great significance to the construction of harmonious society.

The study of this course, let learners feel the music the charm of art, to improve the aesthetic perception of their own and edify sentiment; it implies enlightenment on emotion, permeability, the realization of moral education moral purification and the promotion of personality; it is the cultural life of the general public participants, let the people to pursue the perfect fusion of secular and elegant in art for enjoyment, to realize man's comprehensive development.

Nowadays, with the improvement of the living standards of people's art, learning the piano is more and more popular, the piano has become one of the most direct way to contact and understanding of Western music. The course of piano music, taking as a starting point, to lead the students to further understand the histery development process. By appreciation of music, to learn more about the culture and tradition of the western. Secondly, can also improve students' piano music appreciation ability, establish the correct aesthetic consciousness.

\section{References}

[1] Jianhua Zhang, Zhe Zhang, Zhen Ge, General Education and Internet, Advances in Education Research/ Volume 22/ p.68.

[2] Zhe Zhang, Jianhua Zhang, Zhen Ge, Comparison of Chinese and German Higher Education, Advances in Education Research/ Volume 22/ p.81.

[3] Jianhua Zhang, Zhen Ge, General Education and Practice in University, Advances in Education Research/ Volume 4/ p.158. 